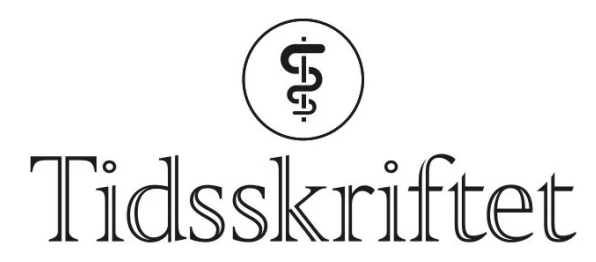

DEN NORSKE LEGEFORENING

\title{
En mann i 6o-årene med kondritt og benmargssvikt
}

NOE Å LARE AV

\section{ØYVIND MIDTVEDT}

omidtved@ous-hf.no

Revmatologisk seksjon

Oslo universitetssykehus, Rikshospitalet

Øyvind Midtvedt er overlege.

Forfatteren har fylt ut ICMJE-skjemaet og oppgir ingen interessekonflikter.

\section{ASBJØRG STRAY-PEDERSEN}

Nyfødtscreeningen

Barne- og ungdomsklinikken

Oslo universitetssykehus

Asbjørg Stray-Pedersen er ph.d., spesialist i medisinsk genetikk, overlege og forsker. Hun er leder i

Norsk forening for medisinsk genetikk.

Forfatteren har fylt ut ICMJE-skjemaet og oppgir ingen interessekonflikter.

\section{HELENA ANDERSSON}

Revmatologisk seksjon

Oslo universitetssykehus, Rikshospitalet

Helena Andersson er ph.d og seksjonsleder. Hun er leder i Norsk revmatologisk forening.

Forfatteren har fylt ut ICMJE-skjemaet og oppgir ingen interessekonflikter.

\section{RAGNAR GUNNARSSON}

Revmatologisk seksjon

Oslo universitetssykehus, Rikshospitalet

Ragnar Gunnarsson er ph.d. og overlege.

Forfatteren har fylt ut ICMJE-skjemaet og oppgir ingen interessekonflikter.

\section{KRISTIAN TVETEN}

Seksjon for medisinsk genetikk

Sykehuset Telemark

Kristian Tveten er ph.d., klinisk laboratoriegenetiker og overingeniør.

Forfatteren har fylt ut ICMJE-skjemaet og oppgir ingen interessekonflikter.

\section{MARYAN MOHAMED ALI}

Vestre Viken, Bærum sykehus og Avdeling for blodsykdommer Oslo universitetssykehus 
Maryan Mohamed Ali er spesialist i indremedisin og blodsykdommer, overlege og stipendiat. Forfatteren har fylt ut ICMJE-skjemaet og oppgir ingen interessekonflikter.

\section{GEIR E. TJØNNFJORD}

Avdeling for blodsykdommer Oslo universitetssykehus

og

Institutt for klinisk medisin

Universitetet i Oslo

Geir E. Tjønnfjord er avdelingsleder og professor.

Forfatteren har fylt ut ICMJE-skjemaet og oppgir ingen interessekonflikter.

\section{En mann i slutten av 6o-årene med terapiresistent relapserende polykondritt og benmargssvikt viste seg å ha et sjeldent og nyoppdaget syndrom som tidligere ikke er beskrevet i Norge.}

En mann i slutten av 6o-årene ble overført til et universitetssykehus med spørsmål om underliggende revmatologisk sykdom. Han hadde seks måneders sykehistorie med redusert allmenntilstand, brystsmerter og episoder med iridosyklitt. I tillegg klaget han over smerter i bakhodet og forbigående smerter $i$ kjeveledd ved tygging. Han hadde ingen synsforstyrrelser eller smerter $i$ bevegelsesapparatet.

Tidligere utredning med biopsi av høyre og venstre arteria temporalis viste normale funn. CT collum, thorax, abdomen og bekken viste ingen lymfeknutepatologi, men en uspesifikk fortetning basalt $i$ venstre lunge. Prokalsitoninverdien var normal, og det var ingen oppvekst i blodkultur. Behandling med doksysyklin i 14 dager hadde ikke hatt effekt. CT aorta viste tegn på veggfortykkelse i venstre arteria subclavia. Blodprøver viste forhøyede verdier av akuttfasereaktanter (tabell 1), noe som ga mistanke om vaskulitt.

\section{Tabell 1}

Blodprøver tatt ved første gangs innleggelse ved universitetssykehus.

\begin{tabular}{|lcr|}
\hline Analyse & Målt verdi & \multicolumn{2}{c|}{ Referanseområde } \\
\hline SR, $\mathrm{mm} / \mathrm{t}$ & 100 & $1-12$ \\
\hline CRP, $\mathrm{mg} / \mathrm{L}$ & 153 & $13,4-17,0$ \\
\hline $\mathrm{Hb}, \mathrm{g} / \mathrm{dL}$ & 9,9 & $82-98$ \\
\hline MCV, fL & 96 & $3,5-10$ \\
\hline Leukocytter, $\times 10^{9} / \mathrm{L}$ & 6,0 & $1,5-7,3$ \\
\hline Nøytrofile granulocytter, $\times 10^{9} / \mathrm{L}$ & 6,8 & $1,1-3,3$ \\
\hline Lymfocytter, $\times 10^{9} / \mathrm{L}$ & 0,7 & $145-390$ \\
\hline Trombocytter, $\times 10^{9} / \mathrm{L}$ & 379 & $36-45$ \\
\hline Albumin, g/L & 35 & $35-105$ \\
\hline ALP, U/L & 245 & $15-115$ \\
\hline GT, U/L & 224 & $105-205$ \\
\hline CK, U/L & 56 & 193 \\
\hline LD, U/L & & \\
\hline
\end{tabular}




\begin{tabular}{|lcr|}
\hline Analyse & Målt verdi & \multicolumn{2}{c|}{ Referanseområde } \\
\hline Troponin T, ng/L & 16 & $<30$ \\
\hline Prokalsitonin, $\mu \mathrm{g} / \mathrm{L}$ & 0,2 & $<0,5$ \\
\hline ACE, $\mathrm{U} / \mathrm{L}$ & 18 & $18-65$ \\
\hline Revmatoid faktor $\operatorname{lgM}, \times 10^{3} \mathrm{IU} / \mathrm{L}$ & 38 & $<25$ \\
\hline Revmatoid faktor $\operatorname{lgA}, \times 10^{3} \mathrm{IU} / \mathrm{L}$ & 2 & $<25$ \\
\hline Anti-CCP, U/mL & 2,4 & $>10$ \\
\hline IgG4, g/L & 3,01 & $0,03-2,01$ \\
\hline $\operatorname{IgG}, \mathrm{g} / \mathrm{L}$ & 14,1 & $6,1-14,9$ \\
\hline $\operatorname{IgA}, \mathrm{g} / \mathrm{L}$ & 5,4 & $0,7-4,3$ \\
\hline $\operatorname{Ig} \mathrm{M}, \mathrm{g} / \mathrm{L}$ & 1,2 & $0,4-2,1$ \\
\hline
\end{tabular}

Elektrolytter og lever- og nyreprøver var alle innenfor normale grenser. Proteinelektroforese viste tegn på akuttfasereaksjon, men ingen monoklonal gammopati. Antinuklecre antistoffer (ANA), antistoff mot nøytrofilt cytoplasma-antigen (ANCA) og HLA-B27 ble ikke påvist. Urinstiks viste intet utslag for blod eller protein.

Ved IgG4-relatert sykdom kan konsentrasjonen av serum-IgG4 være forhøyet. IgG4-relatert sykdom er en immunmediert systemsykdom som fører til inflammasjon og fibrose i affiserte organer (1). Sykdommen kan affisere en rekke organer og store blodårer. Pasienten hadde ingen typiske tegn på IgG4-relatert sykdom, som hevelse i tåre- og spyttkjertler, pankreatitt eller retroperitoneal fibrose. Forhøyet serumkonsentrasjon av IgG4 kan også forekomme som tilfeldig funn ved andre inflammatoriske tilstander (2 2 .) Siden det ikke var andre tegn på IgG4-relatert sykdom enn funnet i arteria subclavia, gikk vi bort fra denne diagnosen.

Ved kryoglobulinassosiert vaskulitt kan test for revmatoid faktor av type IgM være positiv. Kryoglobuliner er immunglobuliner som presipiterer in vitro ved temperatur under kroppstemperatur, og som løser seg opp igjen ved $37^{\circ} \mathrm{C}$. Ved kryoglobulinassosiert vaskulitt dannes det immunkomplekser som fører til vaskulitt i små til mellomstore blodårer. Pasienten hadde ingen Raynaud-fenomener eller utslett, som er vanlig ved denne typen vaskulitt.

Videre hadde pasienten ingen påfallende smerter eller morgenstivhet i skuldre og hofter, slik som er vanlig ved polymyalgia revmatika. Konsentrasjonen av angiotensinkonverterende enzym (ACE) var normal, og det var ingen andre holdepunkter for sarkoidose.

PET-CT-undersøkelse med ${ }^{18} \mathrm{~F}-f l u o r d e o k s y g l u k o s e\left({ }^{18} \mathrm{~F}-\mathrm{FDG}\right)$ utført ved innleggelsen viste økt opptak av ${ }^{18}$ F-fluordeoksyglukose i torakalaorta, buekaravganger og perikard (figur 1). 


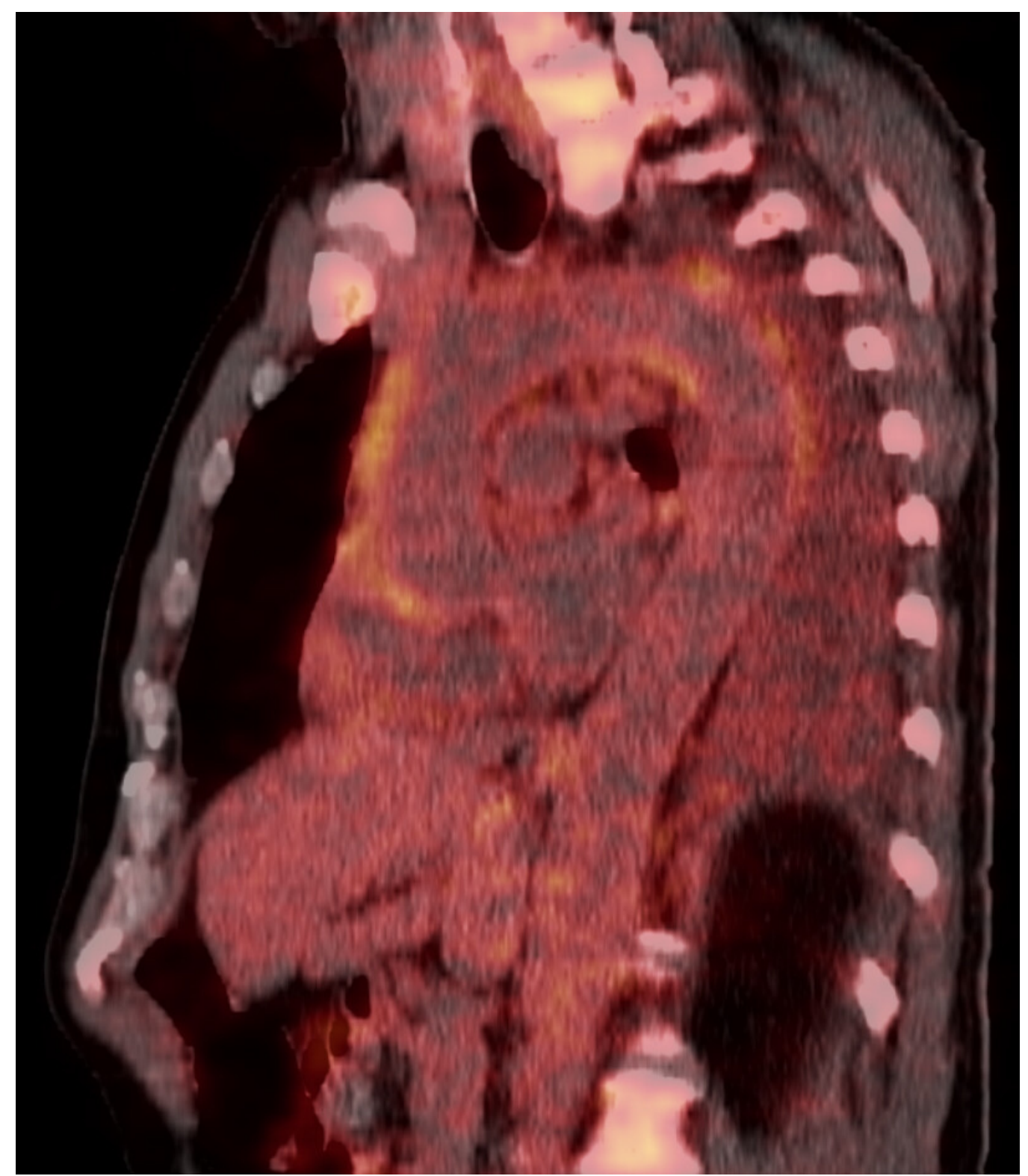

Figur 1 PET-unders $\varnothing$ kelse med ${ }^{18} \mathrm{~F}$-fluordeoksyglukose kombinert med CT $\left({ }^{18} \mathrm{~F}\right.$-FDG-PET-CT) viser torakalaorta (sagittalt snitt). Fargene viser ${ }^{18} \mathrm{~F}-\mathrm{FDG}$-opptak på CT-bakgrunn (økende opptak fra rødt til gult). Det ses økt opptak i aortaveggen i aorta ascendens og aortabuen. Forandringene tolkes som økt metabolisme sekundært til inflammasjon. Bilde: James Patrick Connelly, Oslo universitetssykehus.

Det var også økt opptak av ${ }^{18} \mathrm{~F}$-fluordeoksyglukose i benmarg og lymfeknuter, som ble vurdert å vcere reaktive forandringer. I tillegg ble det funnet et infiltrat $i$ venstre lunges underlapp og pleuravceske (figur2). 


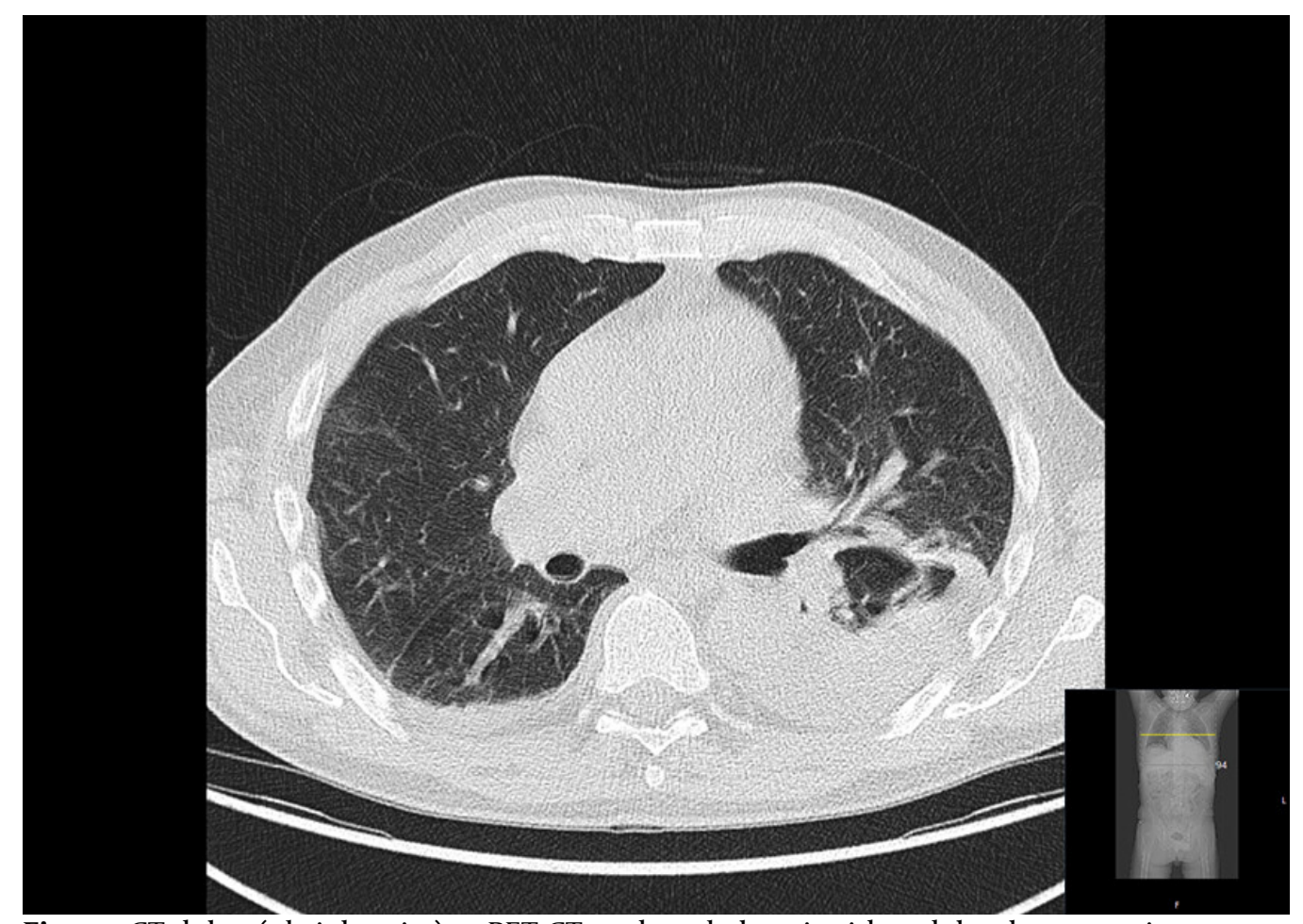

Figur 2 CT-delen (aksialt snitt) av PET-CT-undersøkelsen i midtre del av lungene viser et infiltrat i venstre underlapp og begynnende infiltrat på høyre side. Bilde: James Patrick Connelly, Oslo universitetssykehus.

Tilstanden ble oppfattet som ekstrakraniell kjempecellearteritt. Diagnosen ble stilt på bakgrunn av følgende symptomer og funn: redusert allmenntilstand, smerter i brystet, hodet og kjeveledd, veggfortykkelse i venstre arteria subclavia, økt opptak av ${ }^{18}$ F-fluordeoksyglukose i store blodårer og forhøyede verdier av akuttfasereaktanter.

Man startet immunhemmende behandling med prednisolon $1 \mathrm{mg} / \mathrm{kg}$. Pasienten ble raskt bedre, og akuttfasereaktantnivåene falt tilfredsstillende før hjemreise (CRP $22 \mathrm{mg} / \mathrm{L}$ ).

Kjempecellearteritt er en vaskulittsykdom som affiserer store blodårer. I typiske tilfeller angripes arteria temporalis, og histologisk undersøkelse viser betennelse i blodåreveggen. Biopsier av denne pasientens temporalarterier var normale. Når temporalarteriene ikke er affisert, betegnes tilstanden ekstrakraniell kjempecellearteritt (3).

Kjempecellearteritt affiserer personer over 50 år, og årlig insidens i Sør-Norge er beregnet til 16,8 per 100 ooo i aldersgruppen $\geq 50$ år (4). Lungefortetning er ikke vanlig ved denne sykdommen. Andre årsaker som malignitet og infeksjon kunne ikke forklare funnene i de store blodårene, og ble vurdert som lite sannsynlige. God respons på behandling med prednisolon støttet opp om kjempecellearteritt som diagnose.

Fem måneder etter innleggelsen stod pasienten på behandling med prednisolon 17,5 mg/døgn i tillegg til metotreksat $15 \mathrm{mg} / \mathrm{uke}$, det siste som steroidsparende behandling. Blodprøver viste SR $53 \mathrm{~mm} / \mathrm{t}$ (referanseområde 1-12), CRP $4 \mathrm{mg} / \mathrm{L}(<4), \mathrm{Hb}$ 13,5 g/dL (13,4-17,0), MCV 108 fL (82-98), leukocytter $6,2 \times 10^{9} / \mathrm{L}\left(3,5^{-10} \times 10^{9}\right)$, nøytrofile granulocytter $5,1 \times 10^{9} / \mathrm{L}\left(1,5-7,3 \times 10^{9}\right)$, lymfocytter $0,7 \times 10^{9} / \mathrm{L}$ $\left(1,1-3,3 \times 10^{9}\right)$ og trombocytter $221 \times 10^{9} / \mathrm{L}\left(145-390 \times 10^{9}\right)$.

Pasienten responderte ikke tilfredsstillende på behandlingen med prednisolon og metotreksat. Det ble fors $ø$ kt behandling med interleukin 6-hemmeren tocilizumab (8 mg/kg intravenøst hver fjerde uke), deretter med interleukin 1-hemmeren anakinra (10o mg subkutant daglig) og TNF- $\alpha$-hemmeren infliksimab ( $5 \mathrm{mg} / \mathrm{kg}$ intravenøst), men alle ble avsluttet pga. bivirkninger eller manglende effekt. Tjue måneder etter første innleggelse blusset sykdommen opp med hevelse og rødhet $i$ ørebrusk og neserot som ved kondritt. Blodprøver viste SR > $100 \mathrm{~mm} / \mathrm{t}$, CRP $79 \mathrm{mg} / \mathrm{L}, \mathrm{Hb} 10,0 \mathrm{~g} / \mathrm{L}, \mathrm{MCV} 114 \mathrm{fL}$, leukocytter $4,4 \times 10^{9} /$ L, lymfocytter $0,7 \times 10^{9} /$ L og trombocytter $79 \times 10^{9} /$ L. Pasienten tilfredsstilte McAdam-kriteriene for relapserende polykondritt, og diagnosen ble derfor endret. Det ble startet behandling med TNF- $\alpha$-hemmeren adalimumab (40 mg subkutant annenhver uke), men behandlingen ble avsluttet etter kort tid pga. manglende effekt og bivirkninger. 
Relapserende polykondritt er en sjelden immunmediert systemsykdom som kan affisere samtlige av kroppens organer med hyalin brusk og bindevev, f.eks. øre, nese, øye, store luftveier, ledd, hjerte, kar og hud (5). Behandling av relapserende polykondritt kan være utfordrende. De fleste pasienter vil ha behov for annen immunhemmende behandling enn glukokortikoider for å stabilisere tilstanden. Mest vanlig er bruk av metotreksat, azatioprin, syklofosfamid eller biologiske immunhemmende medikamenter som TNF- $\alpha$ hemmere. Underliggende hematologisk sykdom som myelodysplasi er beskrevet å være assosiert med relapserende polykondritt (므). I en studie på 200 pasienter med relapserende polykondritt ble det rapportert at $22(11 \%)$ hadde myelodysplasi, hvorav flertallet var menn (18 av 22) (ㅁ).

Til tross for pågående behandling progredierte sykdommen. Pasienten utviklet makrocytcr anemi med $\mathrm{Hb}$ 7-8 g/dL og MCV > 105 fL, og trombocytopeni med trombocytter $20-30 \times 10^{9} / \mathrm{L}$. I et benmargsutstryk ble det bemerket vakuoler i cytoplasma i erytroide og myeloide forstadier (figur 3), men gjentatte benmargsutstryk og benmargsbiopsier ble vurdert som inkonklusive med tanke på myelodysplasi eller annen benmargssykdom. Utredning med eksomsekvensering av DNA fra blod og munnslimhinne ble utført. Eksomdataene ble filtrert med genpanel rettet mot arvelig anemi eller benmargssvikt og immunsviktsykdommer (7). Genpanelanalysen inkluderte inspeksjon av mer enn 300 gener, og det ble ikke påvist genavvik. Undersøkelser med tanke på amyloidose og Whipples sykdom ga også negative resultater.

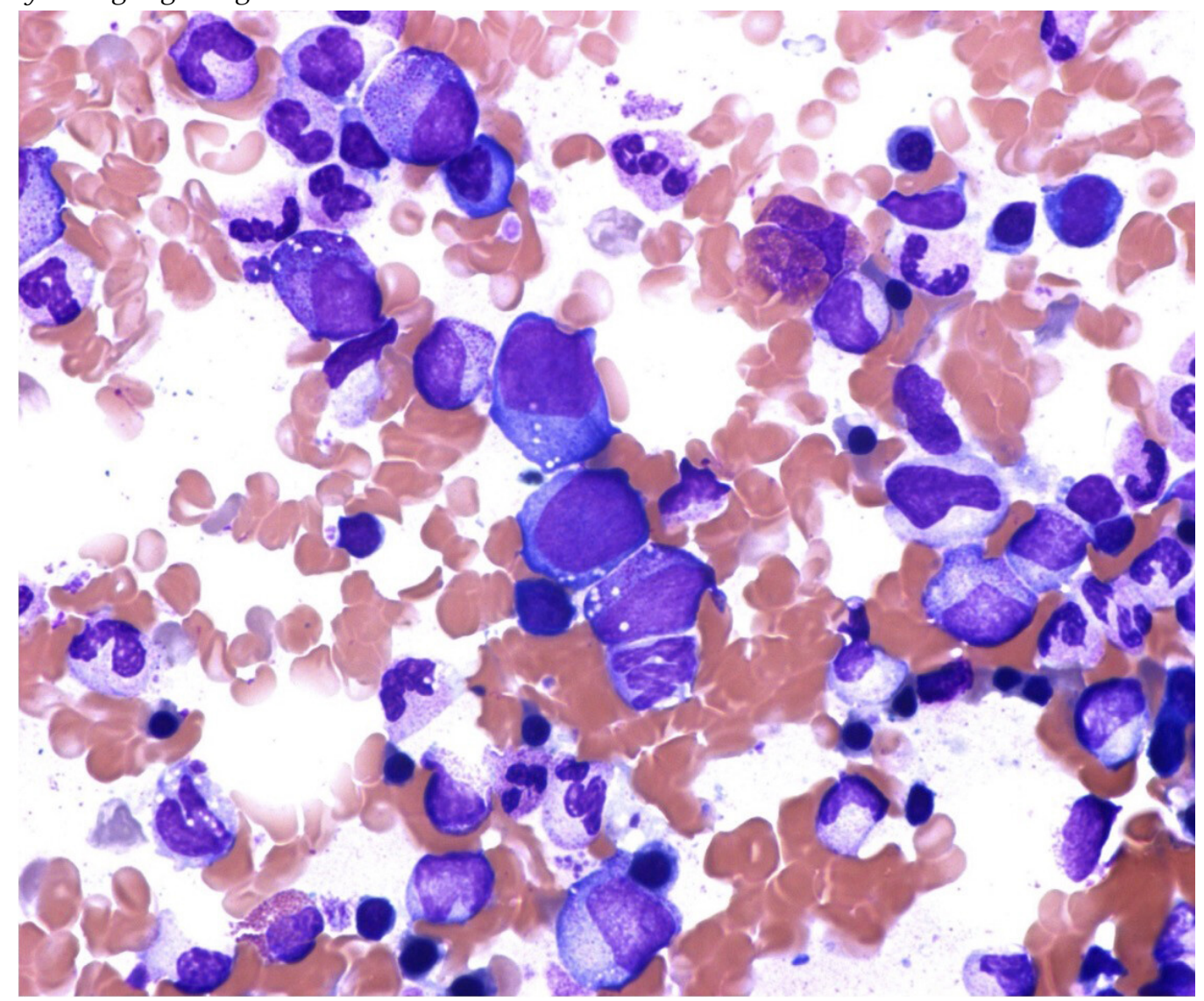

Figur 3 Vakuolisering i erytroide og myeloide forløpere. Foto: Signe Spetalen, Oslo universitetssykehus.

I årene som fulgte, ble det forsøkt ulike immunhemmende medikamenter som azatioprin (200 mg/døgn), ciklosporin (40o mg/døgn), mykofenolatmofetil (1 $\mathrm{g} /$ døgn) og immunglobulin (2 $\mathrm{g} / \mathrm{kg}$ intravenøst hver fjerde uke), men alle behandlingene ble avsluttet på grunn av manglende effekt. Under hele sykdomsforløpet ble pasienten behandlet med prednisolon, men det var som regel behov for doser på over $20 \mathrm{mg}$ daglig. Anemi og trombocytopeni ble fors $ø$ kt behandlet med erytropoietin, granulocyttkolonistimulerende faktor (G-CSF) og eltrombopag, men uten effekt. De siste årene trengte han blodtransfusjoner hver 7.-10. dag. 
Åtte år etter første innleggelse ble mannen innlagt på lokalsykehus med mellomørebetennelse. Han ble behandlet med paracentese, penicillin, gentamicin og erytrocytt- og trombocyttransfusjoner, men døde under oppholdet.

Pasienten ble ikke glemt. Behandlende leger fattet mistanke om at han kunne ha hatt et nylig beskrevet syndrom. I samråd med ektefellen ble det åtte måneder etter at han var død, utført en rask in silico-reanalyse av eksomdataene. Reanalysen viste at han hadde en variant i genet UBA1 (NM_oo3334.3:c.122T>C) med variantallelfrekvens (VAF) på 79,5\% i blod-DNA. Varianten kunne ikke gjenfinnes i munnslimhinne-DNA.

Riktig diagnose kunne endelig stilles. Missensvarianten c.122T $>\mathrm{C}$ i UBA1-genet med aminosyreendring p.Met41Thr er tidligere rapportert som årsak til VEXAS-syndrom (모).

\section{Diskusjon}

VEXAS-syndrom er et nylig beskrevet syndrom (모). VEXAS er et akronym som står for vakuoler, E1-enzym, X-bundet, autoinflammatorisk og somatisk. Vanlige symptomer og funn ved VEXAS-syndrom er feber, redusert allmenntilstand, kondritt i øre og nese, utslett, lungeinfiltrater, venøs tromboembolisme, makrocytær anemi, trombocytopeni, forhøyede verdier av akuttfasereaktanter og vakuoler i benmargsceller.

Syndromet skyldes en ervervet mutasjon med endring i en spesifikk aminosyre, p.Met41, i genet som koder for ubikvitinaktiverende enzym 1 (UBA1). Genavviket forårsaker en defekt $\mathrm{i}$ enzymet som initierer ubikvitinering, en intracellulær prosess med posttranslasjonell modifisering av proteiner. Dette fører til aktivering av immunapparatet og systemisk inflammasjon.

UBA1-genet er lokalisert på X-kromosomet, og syndromet opptrer derfor oftest hos menn (ㅁ). Genfeilen er alltid ervervet (og somatisk). Beck og medarbeidere identifiserte 25 menn med somatisk genavvik i $U B A 1$ ( $\underline{8})$. 15 av dem hadde fått diagnosen relapserende polykondritt, 8 akutt febril nøytrofil dermatose (Sweets syndrom), 3 polyarteritis nodosa og 1 kjempecellearteritt. Videre var det 6 pasienter med myelodysplastisk syndrom og 5 pasienter med myelomatose eller monoklonal gammopati med ukjent betydning.

Hematologiske manifestasjoner er vanlig ved VEXAS-syndrom (모). I benmargsutstryk kan en se vakuoler i cytoplasma til erytroide og myeloide forstadier (figur 3). Slike vakuoler er ikke spesifikke for VEXAS-syndrom, men funn av cytoplasmatiske vakuoler i benmargsceller bør vekke mistanke om det. Tilstanden har mange likhetstrekk med de autoimmune manifestasjonene man kan se hos pasienter med myelodysplasi (9.).

Vår pasient utviklet makrocytær anemi og trombocytopeni. Ferrada og medarbeidere fant at menn med kondritt i øre eller nese ledsaget av MCV $>100 \mathrm{fL}$ og trombocyttkonsentrasjon $<200 \times 10^{9} / \mathrm{L}$ har en sensitivitet og spesifisitet for VEXAS-syndrom på henholdsvis $100 \%$ og $96 \%$ (10). Revmatologisk seksjon ved Oslo universitetssykehus har et register for pasienter med systemisk bindevevssykdom, Norsk systemisk bindevevssykdom og vaskulittregister (NOSVAR). Pasienten ble allerede ved første innleggelse inkludert i registeret.

Etterundersøkelse av blodprøver tatt i forbindelse med registrering viste at genfeilen var til stede ved debut av sykdommen. Det er foreløpig registrert 20 pasienter med relapserende polykondritt i NOSVAR-registeret ( 7 menn og 13 kvinner). Vi har gjennomgått disse og ikke funnet flere med relapserende polykondritt med MCV $>100 \mathrm{fL}$ og trombocytter $<200 \times$ 109/L, altså prøvesvar som kunne ha gitt mistanke om VEXAS-syndrom.

Patogenesen ved VEXAS-syndrom er ikke fullstendig klarlagt. Et ervervet genavvik som medfører aktivering av immunapparatet og systemisk inflammasjon, er et interessant funn. Muligens vil en finne somatiske varianter i andre gener ved flere autoimmune sykdommer.

VEXAS-syndrom kan være en del av forklaringen på hvorfor det er rapportert økt forekomst av hematologisk sykdom hos pasienter med relapserende polykondritt, især menn. 
VEXAS-syndrom er nylig beskrevet, og det foreligger ingen retningslinjer for behandling. De rapporterte tilfellene er blitt behandlet med glukokortikoider og andre immunhemmende medikamenter, inkludert biologiske legemidler. Syndromet er som regel terapiresistent og ender ofte med fatalt utfall. Av de 25 første pasientene som ble beskrevet med syndromet, var 10 døde ( $\underline{8})$. Bourbon og medarbeidere har rapportert 11 pasienter med VEXAS-syndrom (11). De fant en femårsoverlevelse på $63 \%$. Av 11 pasienter var det kun én som i lang tid ( 87 måneder) ikke mottok immunhemmende behandling. Det kan tyde på at syndromet kan ha et indolent forløp hos noen få. De resterende pasientene hadde fått behandling med glukokortikoider og andre medikamenter, hvorav azacitidin, ruksolitinib og tofacitinib så ut til å være mest lovende (1ㅡ). Med tiden vil en få mer erfaring med behandling. Så langt ser immunhemmende behandling ikke ut til å ha tilstrekkelig effekt. Behandling med allogen stamcelletransplantasjon har nylig vist lovende resultater (12). Slik behandling kan være kurativ, men er ikke uten risiko, og det er fortsatt usikkert hvilke pasienter med VEXAS-syndrom som bør få tilbud om dette.

\section{KONKLUSJON}

Hos middelaldrende menn med uklar inflammasjon som ledsages av kondritt, utslett og lungeinfiltrat, og særlig hvis det i tillegg foreligger MCV > $100 \mathrm{fL}$ og trombocyttkonsentrasjon $<200 \times 10^{9} / \mathrm{L}$, bør VEXAS-syndrom mistenkes. Diagnosen bekreftes med påvisning av mutasjon i UBA1-genet (13). Syndromet er nylig beskrevet, og vår pasient døde før syndromet var kjent. Så langt vi kjenner til, er dette det første beskrevne tilfellet av VEXAS-syndrom i Norge. Ved revmatologisk seksjon ved Oslo universitetssykehus har vi i ettertid sett seks nye tilfeller av tilstanden. Syndromet er sjeldent, men sannsynligvis underdiagnostisert pga. manglende kjennskap.

For legene som behandlet pasienten gjennom mange år, og ikke minst for de pårørende, var det en lettelse at en endelig kunne stille riktig diagnose.

Forfatterne takker Trine Prescott og Lars Retterstøl for gjennomlesning og verdifulle kommentarer.

Pasientens pårørende har gitt samtykke til at artikkelen blir publisert.

Artikkelen er fagfellevurdert.

\section{REFERENCES}

1. Vikse J, Håland S, Norheim KB. IgG4-relatert sykdom. Tidsskr Nor Legeforen 2017; 137: 1201-5. [PubMed][CrossRef]

2. Carruthers MN, Khosroshahi A, Augustin T et al. The diagnostic utility of serum IgG4 concentrations in IgG4-related disease. Ann Rheum Dis 2015; 74: 14-8. [PubMed][CrossRef]

3. Lensen KDF, Voskuyl AE, Comans EFI et al. Extracranial giant cell arteritis: A narrative review. Neth J Med 2016; 74: 182-92. [PubMed]

4. Andersen JB, Myklebust G, Haugeberg G et al. Incidence trends and mortality of giant cell arteritis in southern Norway. Arthritis Care Res 2021; 73: 409-14. [PubMed][CrossRef]

5. Lilleby V, Palm $\emptyset$, Andersson H et al. En mann i 6o-årene med heshet, pustevansker og brystsmerter. Tidsskr Nor Legeforen 2012; 132:308-11. [PubMed][CrossRef]

6. Francès C, Rassi RE, Laporte JL et al. Dermatologic manifestations of relapsing polychondritis. Medicine (Baltimore) 2001; 80: 173-9. [PubMed][CrossRef]

7. Sørensen IW, Prescott T, Rustad CF et al. Genpaneltesting. Tidsskr Nor Legeforen 2020; 140: 224-7. [PubMed][CrossRef]

8. Beck DB, Ferrada MA, Sikora KA et al. Somatic mutations in UBA1 and severe adult-onset autoinflammatory disease. N Engl J Med 2020;383: 2628-38. [PubMed][CrossRef] 
9. Grignano E, Jachiet V, Fenaux P et al. Autoimmune manifestations associated with myelodysplastic syndromes. Ann Hematol 2018; 97: 2015-23. [PubMed][CrossRef]

10. Ferrada MA, Sikora KA, Luo Y et al. Somatic mutations in UBA1 define a distinct subset of relapsing polychondritis patients with VEXAS syndrome. Arthritis Rheumatol 2021; 73: 1886-95. [PubMed] [CrossRef]

11. Bourbon E, Heiblig M, Gerfaud Valentin M et al. Therapeutic options in VEXAS syndrome: insights from a retrospective series. Blood 2021; 137:3682-4. [PubMed][CrossRef]

12. Diarra A, Duployez N, Fournier E et al. Successful allogeneic hematopoietic stem cell transplantation in patients with VEXAS syndrome: a 2-center experience. Blood Adv 2022; 6: 998-1003. [CrossRef]

13. Norsk portal for medisinsk-genetiske analyser. https://genetikkportalen.no Lest 18.10.2021.

Publisert: 28. februar 2022. Tidsskr Nor Legeforen. DOI: 10.4045/tidsskr.21.0370

Mottatt 30.4.2021, første revisjon innsendt 16.7.2021, godkjent 8.10.2021.

Publisert under åpen tilgang CC BY-ND. Lastet ned fra tidsskriftet.no 26. april 2023. 